\title{
SISTEM INFORMASI MANAJEMEN AKADEMIK TKK BERBASIS WEB (STUDI KASUS : TKK TEGALJAYA-DALUNG)
}

\author{
Nesa Padmawati ${ }^{1)}$ Made Agung Raharja ${ }^{2)}$ Agus Tommy Adi Prawira Kusuma ${ }^{3)}$ \\ Program Studi Teknik Informatika ${ }^{2}$ \\ Program Studi Sistem Informasi ${ }^{1)}$ 3) \\ Fakultas Ilmu Kesehatan Sains dan Teknologi Universitas Dhyana Pura, Bali. ${ }^{1)}$ 2) 3) \\ padmawatinesa@gmail.com ${ }^{1)}$ agungraharja@undhirabali.ac.id ${ }^{2)}$ \\ agustommyadi@undhirabali.ac.id ${ }^{3)}$
}

\begin{abstract}
The ever-evolving information technology drives people to be creative and innovative. TKK Tegaljaya is an educational institution that conducts various activities. But amid advances in information technology is increasingly sophisticated, until now TKK Tegaljaya not have their own information system and still use the manual way. Therefore, an academic management information system is needed to manage it.

Research conducted in this case is Interview (Interview), Observation (Observation), and Literature Studies. The method used in the design of this system using the method of XP (Extreme Programming). The language used is PHP and database design using MySQL.

The results of this study indicate that using a web-based academic management information system to facilitate the Administration and Class Guardian to manage academic management, especially in the processing and data collection of student report cards more effectively and efficiently than the existing system.
\end{abstract}

Keywords: Academic Management Information System, XP, Student Values

\begin{abstract}
ABSTRAK
Teknologi informasi yang terus berkembang mendorong manusia untuk selalu kreatif dan inovatif. TKK Tegaljaya merupakan suatu instansi pendidikan yang melakukan berbagai macam kegiatan. Namun ditengah kemajuan teknologi informasi yang semakin canggih, sampai saat ini TKK Tegaljaya belum memiliki sistem informasi sendiri dan masih menggunakan cara manual. Untuk itu, maka diperlukan suatu sistem informasi manajemen akademik untuk mengaturnya. Penelitian yang dilakukan dalam hal ini yaitu Wawancara (Interview), Pengamatan (Observasi), dan Studi Literatur. Metode yang digunakan dalam perancangan sistem ini menggunakan metode XP (Extreme Programming). Bahasa yang digunakan adalah PHP dan perancangan database nya menggunakan MySQL. Hasil penelitian ini menunjukkan bahwa menggunakan sistem informasi manajemen akademik berbasis web dapat memudahkan Tata Usaha dan Wali Kelas untuk mengatur manajemen akademik khususnya dalam pengolahan dan pendataan rapor siswa lebih efektif dan efisien dibanding dengan sistem yang ada sebelumnya.
\end{abstract}

Kata Kunci : Sistem Informasi Manajemen Akademik, XP, Nilai Siswa 


\section{PENDAHULUAN}

Teknologi informasi yang terus berkembang mendorong manusia untuk selalu kreatif dan inovatif. Perkembangan teknologi informasi ini dapat berupa sistem informasi yang memberikan informasi secara tepat, cepat dan akurat. Sistem informasi yang tepat dapat membantu proses pengambilan keputusan untuk pemenuhan kebutuhan pengolahan data, rencana operasional dan sasaran yang akan dicapai oleh suatu instansi. Hal ini disebabkan karena tujuan dari pengambilan keputusan adalah membantu instansi dalam menentukan sikap dan menjadikannya sebagai tolak ukur kinerja instansi tersebut di masa depan.

Sistem informasi manajemen adalah suatu metode untuk menghasilkan informasi yang tepat waktu bagi manajemen tentang lingkungan luar organisasi dan kegiatan operasi di dalam organisasi dengan tujuan untuk menunjang proses pengambilan keputusan (Sutabri, 2005).

Sistem informasi manajemen akademik TKK Tegaljaya dapat memudahkan pegawai dalam mengatur data akademik, maka peneliti memutuskan untuk membuat sistem informasi manajemen akademik TKK berbasis Web. Aplikasi manajemen akademik dikembangkan berbasis Web dengan MySqL sebagai database servernya, sehingga data anak didik, data wali kelas, data kelas, data absen, dan data nilai dapat terintegrasi dan dapat dengan mudah diolah dan diakses oleh banyak komputer.

Tugas akhir ini berjudul "Sistem Informasi Manajemen Akademik TKK berbasis Web pada TKK Tegaljaya" dengan harapan mempermudah pekerjaan guru atau karyawan TKK Tegaljaya sehingga dapat meningkatkan pelayanan kepada siswa dan segala hal yang berhubungan dengan manajemen data akademik siswa.

\section{TINJAUAN PUSTAKA \\ Pengertian Sistem}

Secara sederhana sistem dapat diartikan sebagai suatu kumpulan atau himpunan dari unsure, komponen, atau variabel yang terorganisasi, saling berinteraksi, saling tergantung satu sama lain dan terpadu (Sutabri, 2012).

\section{Pengertian Informasi}

Informasi adalah data yang telah diklasifikasikan atau diolah atau diinterpretasikan untuk digunakan dalam proses pengambilan keputusan (Sutabri, 2012). infomasi adalah data yang diolah menjadi bentuk lebih berguna dan lebih berarti bagi yang menerimanya. Informasi juga disebut data yang diproses atau data yang memiliki arti.

\section{Pengertian Informasi}

Informasi adalah data yang telah diklasifikasikan atau diolah atau diinterpretasikan untuk digunakan dalam proses pengambilan keputusan (Sutabri, 2012). infomasi adalah data yang diolah menjadi bentuk lebih berguna dan lebih berarti bagi yang menerimanya. Informasi juga disebut data yang diproses atau data yang memiliki arti.

\section{Siklus Informasi}

Data merupakan bentuk yang paling sederhana dan belum bisa menjadi suatu informasi. Untuk itu perlu diolah lebih lanjut melalui suatu model. Dari data kemudian diolah dengan model tertentu menjadi informasi. Kemudian penerima menerima informasi tersebut, membuat keputusan dan melakukan tindakan, yang berarti melakukan suatu tindakan yang lain yang akan membuat sejumlah data kembali. Data tersebut akan ditangkap sebagai input diproses kembali lewat suatu model dan seterusnya membentuk suatu siklus. John Burch menyebutkan siklus ini disebut siklus informasi (information cycle) atau siklus pengolahan data (data processing cycle) (Jogiyanto, 2005:8).

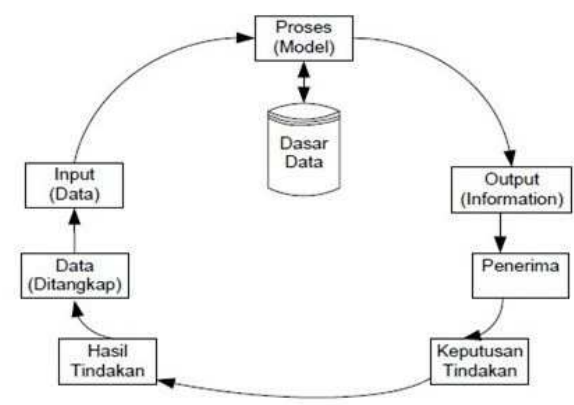

Gambar 1. Siklus Informasi

\section{Pengertian Sistem Informasi}

Sistem informasi adalah suatu sistem di dalam suatu organisasi yang mempertemukan kebutuhan pengolahan transaksi harian yang mendukung fungsi operasi organisasi yang bersifat manajerial dengan kegiatan strategi dari suatu organisasi untuk dapat menyediakan laporan-laporan yang diperlukan oleh pihak luar tertentu (Sutabri, 2012). 


\section{Pengertian Manajemen}

Manajemen sebagai proses atau kegiatan yang menjelaskan apa yang dilakukan manajer pada operasional organisasi mereka untuk merencanakan, mengorganisasikan, memprakarsai dan mengendalikan operasi (Sutabri, 2005).

Pengertian Sistem Informasi Manajemen Sistem Informasi Manajemen didefinisikan sebagai suatu sistem berbasis komputer yang menyediakan informasi bagi beberapa pemakai dengan kebutuhan serupa. Output informasi digunakan oleh manajer maupun non manajer dalam perusahaan untuk membuat keputusan dalam memecahkan masalah (McLedod dalam Yakub, 2012).

Konsep Sistem Informasi akademik

Akademik adalah kegiatan yang dilakukan di dalam lingkungan dunia pendidikan yang berhubungan dengan proses belajar mengajar (Rahayu, Purnama dan Sukadi : 2012). Sedangkan sistem informasi akademik adalah suatu sistem yang dirancang untuk keperluan data-data akademik dengan penerapan teknologi komputer baik hardware maupun software.

\section{Penelitian Relevan}

Menurut Anisyah Puntorukmi pada penelitiannya yang berjudul "Sistem Informasi Pada Taman kanak-kanak Pertiwi 1 Karangpakel Trucuk Klaten Berbasis Web" telah mengakomodasi pihak sekolah dalam menyediakan segala sesuatu yang berhubungan dengan kegiatan pendidikan sekolah yang dengan mudah dapat diakses lewat internet. Berdasarkan hasil dari ketiga penelitian tersebut, terdapat beberapa persamaan dan perbedaan. Persamaan penelitian ini dengan hasil penelitian sebelumnya adalah membuat sistem informasi yang digunakan dalam institusi pendidikan. Sedangkan perbedaannya terdapat pada software yang digunakan untuk membuat sistem informasinya.

\section{Basis Data}

Basis data adalah kumpulan informasi yang disimpan di dalam komputer secara sistematik sehingga dapat diperiksa menggunakan suatu program komputer untuk memperoleh informasi dari basis data tersebut. Database merupakan suatu pengorganisasian data pada media eksternal (disk) dengan tujuan mempermudah pengaksesan (penyimpanan atau pengambilan) data (Kadir, 2009).

\section{Flowchart}

Bagan alir (flowchart) adalah bagan (chart) yang menunjukkan alir (flow) di dalam program atau prosedur sistem secara logika.

\section{Data Flow Diagram}

DFD adalah suatu cara untuk menggambarkan model aliran data. Darimana data berasal, proses apa yang dilalui, apa yang dihasilkan dan kemudian di mana data akan disimpan (Jogiyanto, 1999)

\section{Tabel 1. Data Flow Diagram}

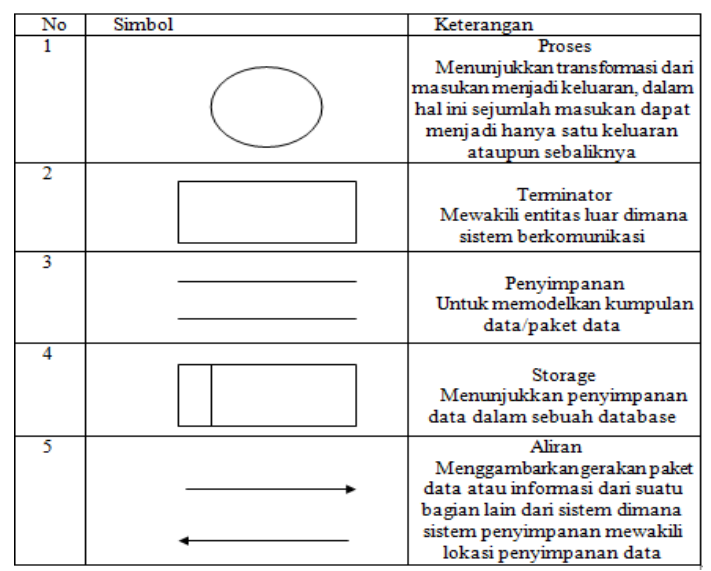

\section{Entity Relationship Diagram}

"Entity Relationship Diagram (ERD) adalah diagram yang menggambarkan keterkaitan antar tabel beserta field-field di dalamnya pada suatu database sistem" (Agus Eka Pratama, 2014:49). Sebuah database memuat minimal sebuah tabel dengan sebuah atau beberapa buah field (kolom) di dalamnya. Namun pada kenyataannya, database lebih sering memiliki lebih dari satu buah tabel (dengan beberapa kolom di dalamnya). Ketiga relasi tersebut yaitu :

- One to One (Satu ke Satu)

- One to Many (Satu ke Banyak)

- Many to Many (Banyak ke Banyak)

Untuk menggambarkan diagram ERD digunakan beberapa simbol diantaranya :

- Entitas (Entity)

- Relasi/Hubungan Antar Entitas (Relationship)

- Atribut

- Alur 


\begin{abstract}
MySQL
"MySQL adalah salah satu jenis database server yang sangat terkenal dan banyak digunakan untuk membangun aplikasi web yang menggunakan database sebagai sumber dan pengolahan datanya" (Arief, 2011d:152).
\end{abstract}

\section{Extreme Programming}

Extreme Programming (XP) merupakan suatu pendekatan berorientasi objek sebagai paradigma pembangunan yang lebih disukai dan meliputi satu set rules dan practices yang berlaku dalam konteks dari 4 aktivitas framework (Pressman, 2010) .

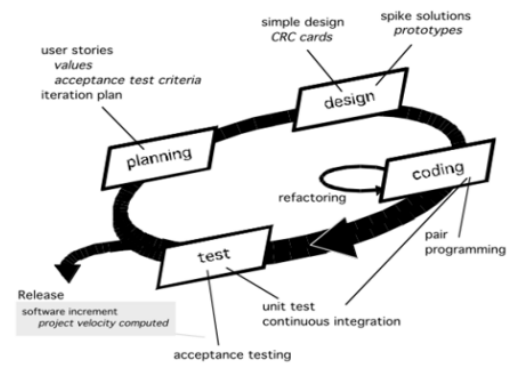

Gambar 2. Extreme Programming

\section{PHP (PHP Hypertext Prepossesor)}

PHP adalah salah satu bahasa pemrograman skrip yang dirancang untuk membangun aplikasi web. Ketika dipanggil dari web browser, program yang ditulis dengan PHP akan di-parsing di dalam web server oleh interpreter PHP dan diterjemahkan ke dalam dokumen HTML, yang selanjutnya akan ditampilkan kembali ke web browser (Budi Raharjo, 2016).

\section{Bootstrap}

Bootstrap merupakan sebuah framework css yang memudahkan pengembang untuk membangun website yang menarik dan responsif. Tidak konsistensinya terhadap aplikasi individual membuat sulitnya untuk mengembangkan dan pemeliharaannya. Bootstrap adalah css tetapi dibentuk dengan LESS, sebuah pre-prosessor yang member fleksibitas dari css biasa.

\section{METODE PENELITIAN}

\section{Metode Pengumpulan Data}

Adapun jenis pengumpulan data yang digunakan dalam penelitian sebagai berikut :

- Wawancara (Interview)

- Pengamatan (Observasi)

- Studi Literatur
Metode Analisis dan Perancangan Sistem

Pada sub bab ini membahas tentang cara dan metode yang digunakan dalam perancangan aplikasi Sistem Informasi Manajemen Akademik TKK berbasis Web yaitu Extreme Programming.

\section{Perancangan Sistem}

Setelah dilakukan analisis dari sistem informasi akademik yang akan dikembangkan, maka langkah selanjutnya adalah membuat desain atau rancangan sistem. Untuk membantu dalam perancangan sistem dibutuhkan alat-alat bantu yang berupa suatu gambar, diagram, atau grafik. Pada metodologi kali ini penulis menggunakan alatalat pengembangan sistem yang terstruktur diantaranya :

\section{Konteks Diagram}

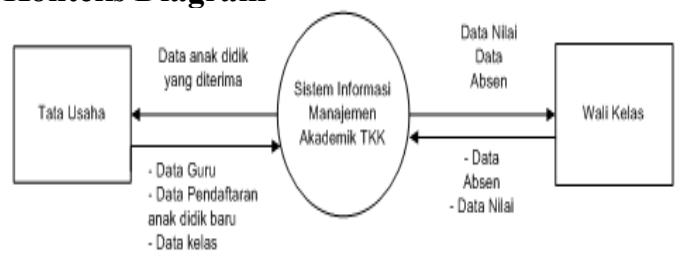

Gambar 3. Konteks Diagram

\section{Data Flow Diagram}

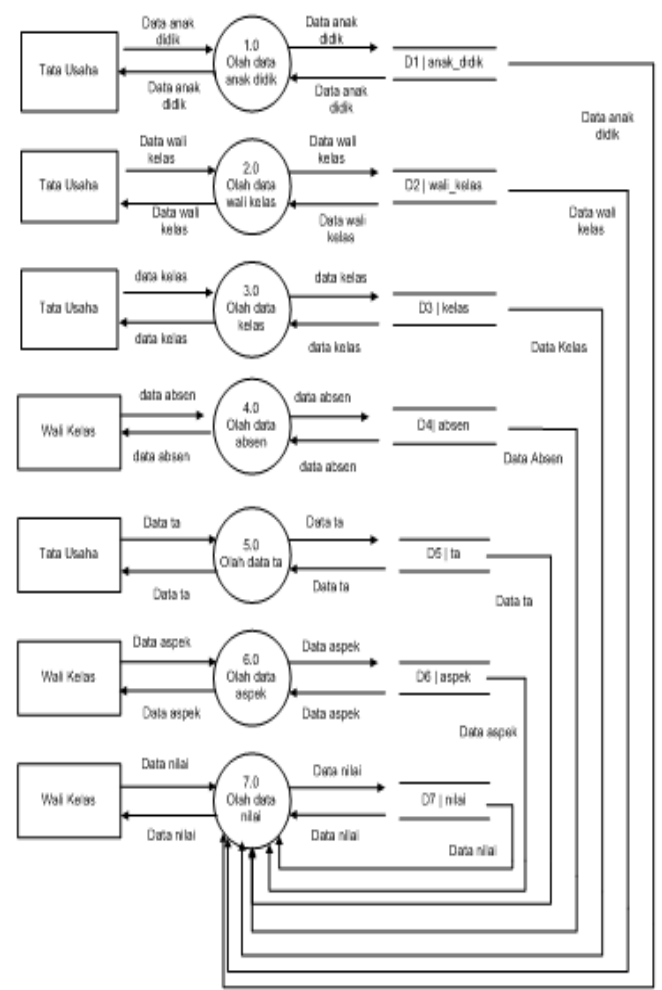

Gambar 4. Data Flow Diagram 


\section{Flowchart}

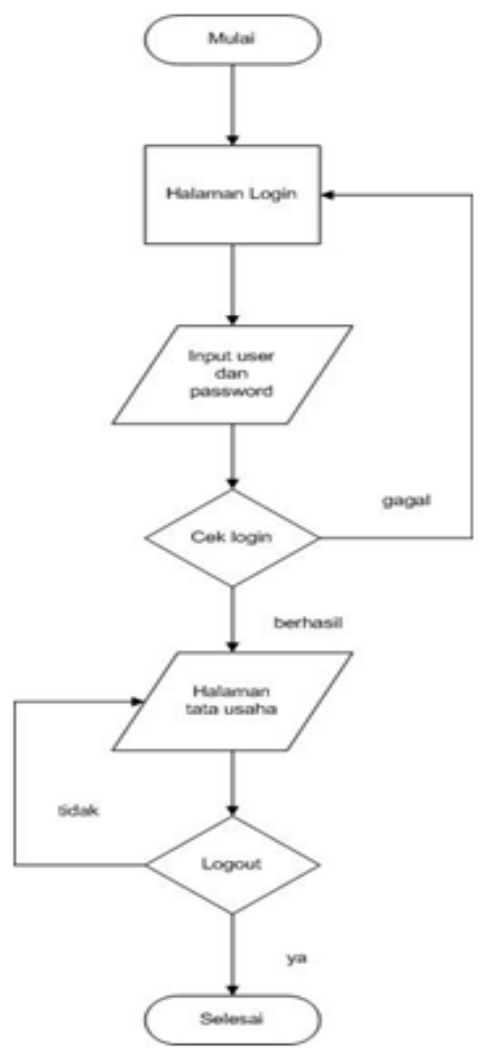

Gambar 5 . Login Tata Usaha

menjelaskan proses login Tata Usaha yang dimulai dari halaman login kemudian input data user dan password, kemudian cek login. Jika login gagal maka akan kembali ke halaman login, dan jika login berhasil maka akan tampil halaman tata usaha. Jika ingin logout maka akan logout jika tidak maka akan kembali ke halaman tata usaha.

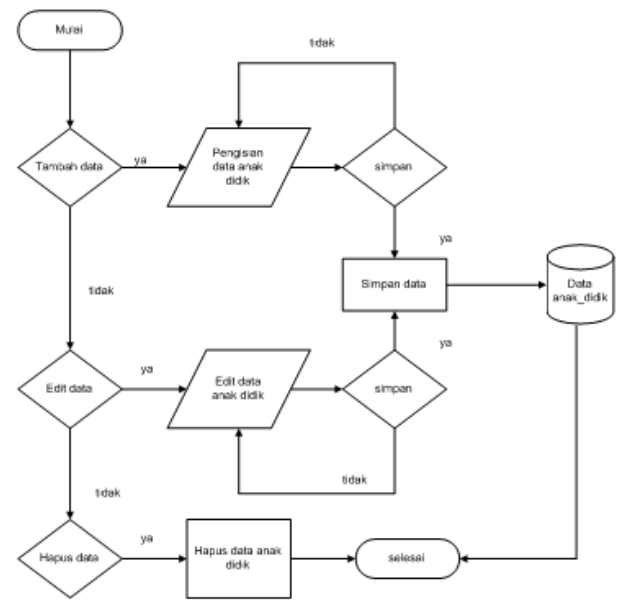

Gambar . Flowchart anak didik menjelaskan proses memasukkan data anak didik, dimulai dari tambah data kemudian setelah melalui proses pengisian data anak didik, data akan disimpan pada database anak didik. Untuk mengubah data dimulai dari menu edit data kemudian akan disimpan kembali ke database anak didik. Untuk menghapus data yang telah disimpan bisa melalui menu hapus data.

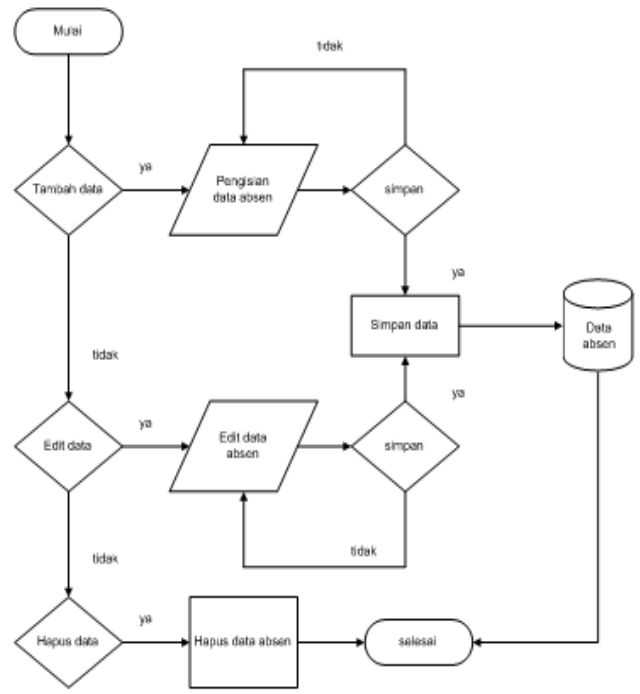

\section{Gambar 6 . Flowchart Absen}

menjelaskan proses memasukkan data absen, dimulai dari tambah data kemudian setelah melalui proses pengisian data absen, data akan disimpan pada database absen. Untuk mengubah data dimulai dari menu edit data kemudian akan disimpan kembali ke database absen. Untuk menghapus data yang telah disimpan bisa melalui menu hapus data.

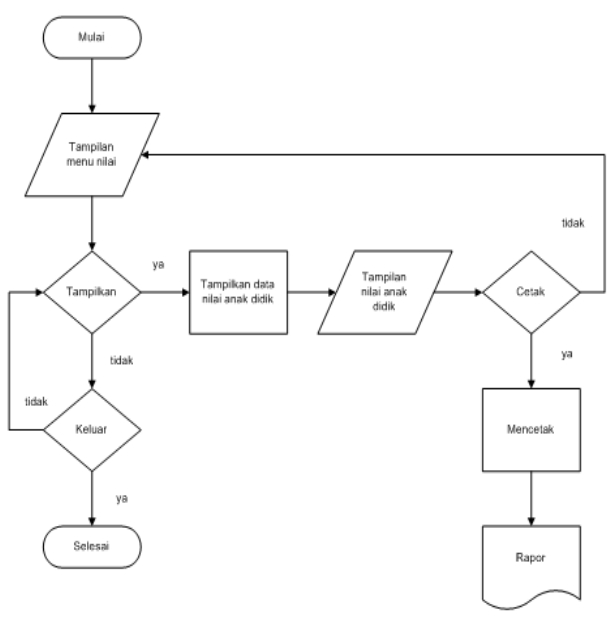

Gambar 7. Flowchart Data Nilai 
menjelaskan proses input data nilai yang dimulai dari tampilan menu nilai, kemudian jika tidak ingin melanjutkan ke proses selanjutnya maka keluar, jika iya maka akan ditampilkan data nilai anak didik. Jika ingin mencetak data nilai anak didik maka hasilnya berupa rapor. Dan jika tidak maka kembali ke tampilan menu nilai.

\section{Entity Relationship Diagram (ERD)}

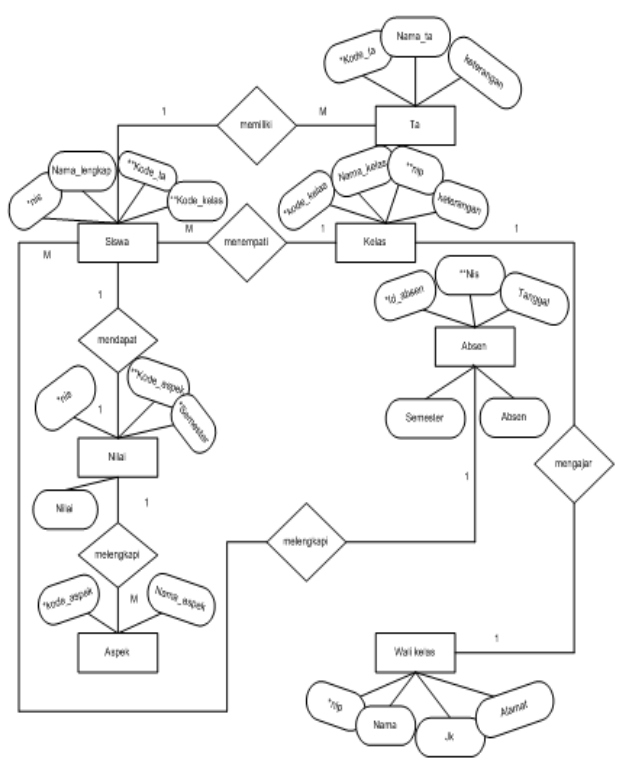

\section{Gambar 8. ERD Sistem Informasi} Manajemen TKK

\section{Relasi Tabel}

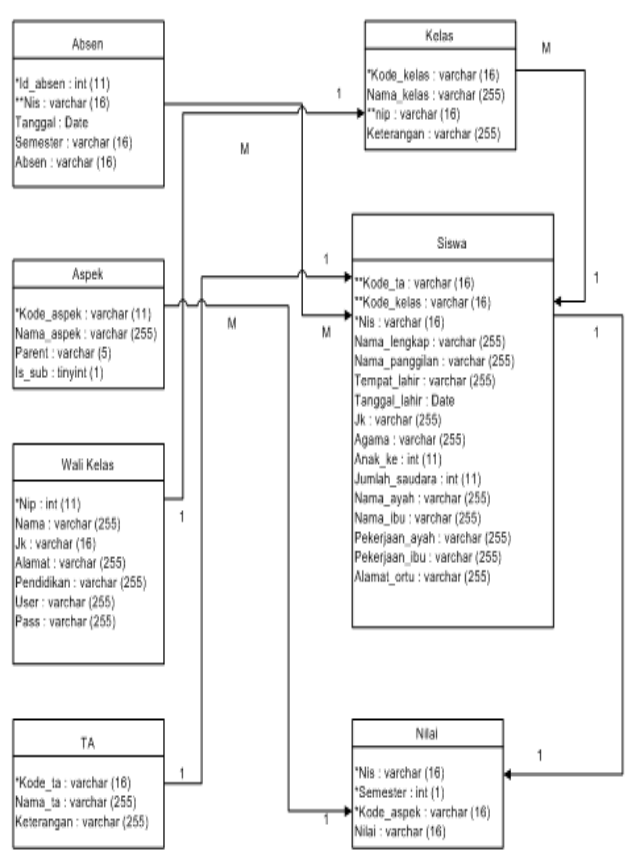

Gambar 9. Relasi Tabel

\section{IMPLEMENTASI SISTEM}

\section{Implementasi}

Pada tahap implementasi ini merupakan terjemahan perancangan berdasarkan hasil analisa pada bab sebelumnya ke dalam bahasa pemrograman yang dapat dimengerti oleh komputer. Aplikasi ini dikembangkan dengan menggunakan bahasa pemrograman PHP dan didesain dengan menggunakan Bootstrap.

\section{Perangkat Lunak Pembangunan}

Perangkat lunak pembangunan menjelaskan perangkat lunak apa saja yang digunakan untuk membangun sistem informasi manajemen akademik TKK berbasis web. Berikut adalah perangkat lunak yang digunakan dalam pembuatan sistem informasi ini adalah sebagai berikut :

\section{Sistem Operasi Windows 7 \\ 2. Xampp \\ 3. MySQL 127.0.0.1 \\ 4. Macromedia Dreamweaver 8 \\ 5. Google Chrome}

\section{Perangkat Keras Pembangunan}

Perangkat keras pembangunan menjelaskan perangkat keras apa saja yang digunakan untuk membangun Sistem Informasi Manajemen Akademik TKK berbasis web. Berikut adalah perangkat keras yang digunakan dalam pembuatan sistem informasi ini sebagai berikut :
1. Laptop HP RAM 2048MB
2. Modem atau koneksi internet dengan kecepatan 64Kbps atau lebih
3. Mouse
4. Hardisk 80GB atau lebih

\section{Implementasi Antarmuka}

Implementasi antarmuka berisi pemaparan setiap antarmuka atau tampilan pada Sistem Informasi Manajemen Akademik TKK berbasis web yang dibangun. Adapun tampilan antarmuka sistem informasi ini adalah sebagai berikut :

\section{Form Login}

Form ini merupakan tampilan dari halaman login sebelum menggunakan aplikasi Sistem Informasi Manajemen Akademik TKK berbasis web. Hak akses dalam menggunakan aplikasi ini dibagi menjadi dua yaitu Tata Usaha, dan Wali kelas. 


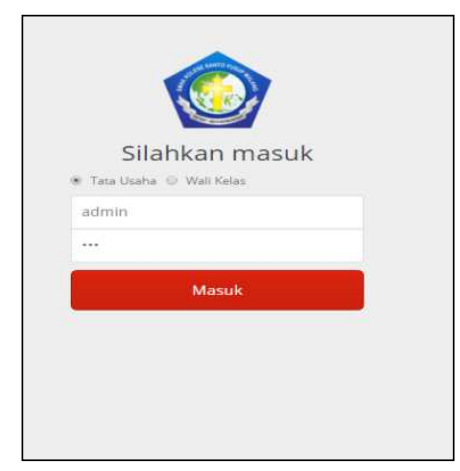

Gambar 10 . Form Login Tata Usaha

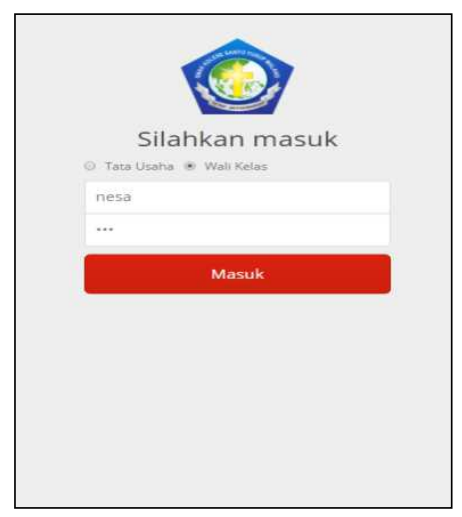

\section{Gambar 11. Form Login Wali Kelas}

\section{Form Menu Utama Tata Usaha}

Form ini merupakan tampilan dari menu utama Tata Usaha. Menu-menu yang hanya dapat diakses oleh tata usaha diOantaranya menu Wali kelas, Tahun Ajaran, Kelas, dan Anak didik.

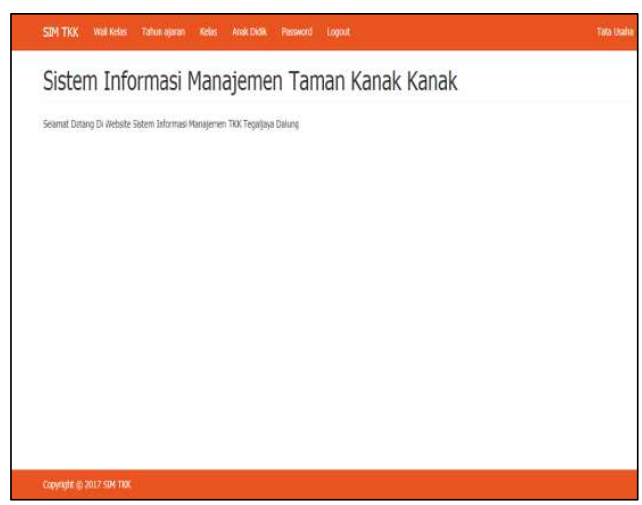

Gambar12 . Form Menu Tata Usaha

\section{Form Menu Utama Wali kelas}

Form ini merupakan tampilan dari menu utama wali kelas. Menu-menu yang hanya dapat diakses oleh wali kelas diantaranya menu anak didik, absen dan nilai.

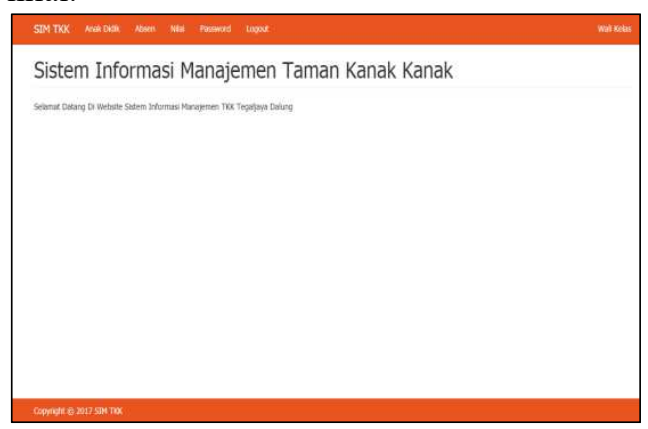

Gambar 13. Form Menu Wali Kelas

\section{Form Input Data Nilai}

Dalam form input data nilai ini, wali kelas menginputkan data nilai dimana dengan keterangan :

MB : Mulai Berkembang

BSH : Berkembang Sesuai Harapan

BSB : Berkembang Sangat Baik

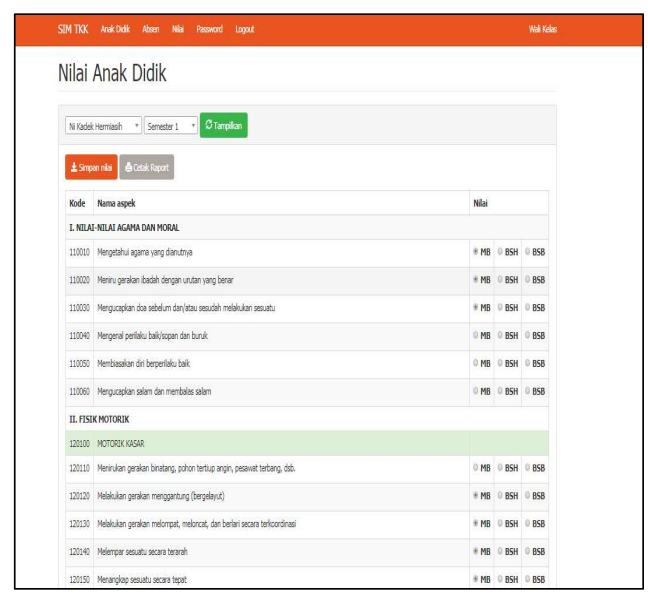

Gambar 14. Form Input Data Anak Didik 


\section{SIMPULAN}

Berdasarkan hasil penelitian dan pembahasan, maka dapat diambil beberapa kesimpulan yaitu :.

- Dengan adanya Sistem Informasi Manajemen Akademik TKK Ber-basis Web sebagai media pen-catatan dalam penerimaan anak didik baru dapat meminimalkan terjadinya penumpukan data atau kekeliruan data anak didik baru.

- Sistem Informasi Manajemen Akademik TKK di TKK Tegaljaya telah berhasil dibuat. Perancangannya dibuat dengan Dia-gram Context, DFD, Flowchart, ERD, dan Relasi Tabel. Pembuatan aplikasi menggunakan database MySQL, bahasa pe-mrograman PHP, kemudian design menggunakan Bootstrap.

- Digunakannya database sebagai pusat penyimpanan data dan informasi akan memudahkan dalam proses pengaksesan, pencarian dan pencetakan laporan dan mencegah terjadinya kehilangan data dan informasi.

- Sistem yang dibangun me-nyediakan fasilitas untuk me-masukkan data anak didik, kelas, wali kelas, absen dan nilai.

\section{DAFTAR PUSTAKA}

[1] Hidayat, R. W. (2010). Sistem Informasi Manajemen Berbasis Client Server di CV. Defourdelta.

[2] Jamaliah. (2011). Sistem Informasi Akademik Berbasis Client Server. (Studi Kasus : Madrasah Tsanawiyah An-Nizhamiyah Cileungsi).

[3] Jogiyanto. (2005). Analisis \& Desain Sistem Informasi: Pendekatan Terstruktur, Teori dan Praktik Aplikasi Bisnis. Yogyakarta: CV Andi Offset.

[4] Jogiyanto, H. (2005). Pengenalan Komputer. Yogyakarta: Penerbit Andi.

[5] Kadir, A. (2009). Dasar Perancangan dan Implementasi Database Relasional. Yogyakarta: CV Andi Offset.

[6] Kurniawan, H. (2010). Pengertian Sistem Informasi Akademik.

[7] Pressman, R. (2010). In Software Engineering: A Practioner's Approach, Seventh Edition :McGraww-Hill (pp. 120-125). New York.

[8] Rahayu, S. P. (2012). Pembuatan Sistem Informasi Akademik Berbasis Short Message Service (SMS) Gateway pada Sekolah Menengah Atas Negeri 2 Pacitan.

[9] Sutabri. (2012). Analisis Sistem Informasi. Yogyakarta: CV Andi Offset.

[10] Sutabri. (2005). Sistem Informasi Manajemen. Yogyakarta: Andi Offset.

[11] Yakub. (2012). Pengantar Sistem Informasi. Yogyakarta: Graha Ilmu. 